\title{
15 A Cattle Market Becomes a University Library in Germany
}

\begin{abstract}
The Hochschule Düsseldorf/University of Applied Sciences Düsseldorf (HSD) moved to a completely new campus in Düsseldorf Derendorf in 2016. The site had been formerly used as a municipal slaughterhouse. The library is in a heritage listed building, an old cattle market hall. This chapter describes the history of the buildings including their original use as municipal slaughterhouse and cattle market hall and their abuse during the Nazi regime in the 1940s as a gathering place for people being deported. The historic context demanded sensitive reuse and provided the impetus to establish a memorial within the building that has now become the Hochschulbibliothek/University Library. The planning process for the reuse of the building is outlined from the viewpoint of the library, and the technical infrastructure, architecture and interior design are described. The historical preservation of the building, the history of the building itself and the requirements regarding the new use influenced the design decisions and provided special challenges to all groups involved in the planning process.
\end{abstract}

Keywords: Academic libraries - Germany; Library buildings - Design and construction; Buildings - Remodelling for other use; Slaughtering and slaughter-houses - Remodelling for other use

\section{Introduction}

In 2016, the Hochschule Düsseldorf/University of Applied Sciences Düsseldorf (HSD) moved to a completely new campus in Düsseldorf Derendorf, Germany. The campus was completed in 2018. The new site had been formerly used as a municipal slaughterhouse. The area features an ensemble of several modern buildings and two listed for preservation. The library is in one of the listed historic buildings, an old cattle market hall.

The first part of the chapter describes the history of the building and its uses until its re-opening in 2016. The second part is dedicated to the design principles that were applied by the architects in the refurbishment process and represents the architects' view on the project. The last part focuses on the needs of the library relating to the use of the building and new opportunities for services that emerged from the architectural design.

2 Open Access. (02021 Katharina Regulski, published by De Gruyter. (c) BY-NC-ND This work is licensed under the Creative Commons Attribution-NonCommercial-NoDerivatives 4.0 International License. 


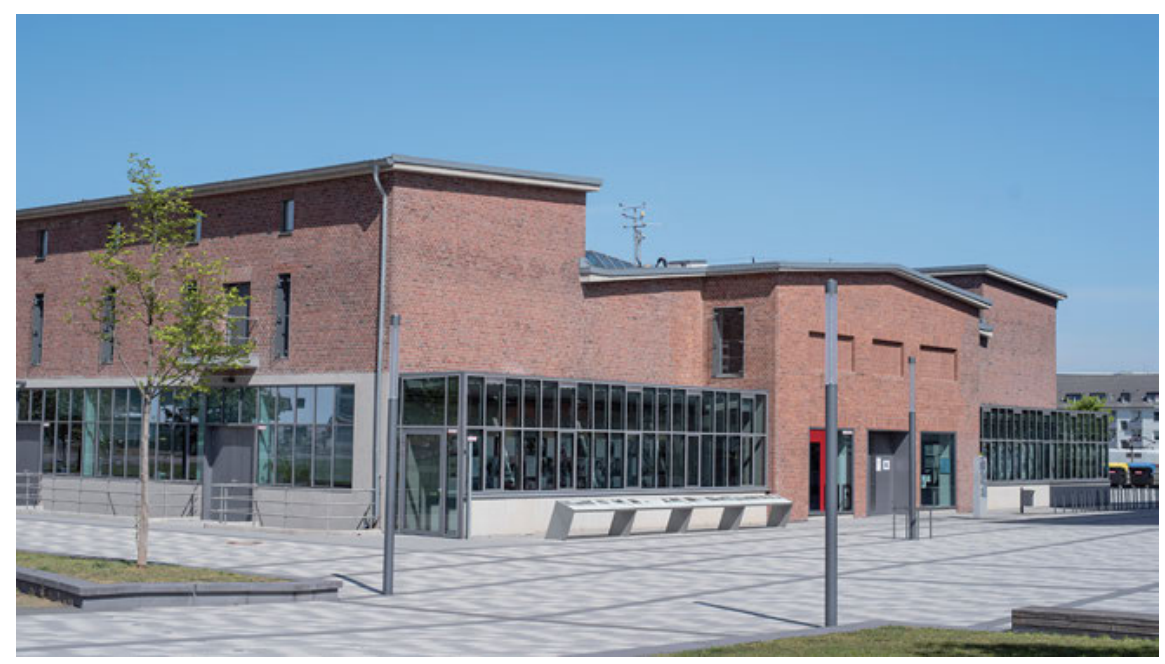

Fig. 1: The former cattle market transformed for library use: iconic architectural characteristics featuring a red brick façade. (c) Chantal Schlenker.

\section{Facts and Figures}

Name: Hochschulbibliothek, Hochschule Düsseldorf/University Library, Düsseldorf University of Applied Sciences

Address: Münsterstraße 156, 40476 Düsseldorf, Germany

Website: http://bib.hs-duesseldorf.de

Opening: February 2016

Builder: Bau- und Liegenschaftsbetrieb NRW Niederlassung Düsseldorf

Architect: Nickl \& Partner Architekten https://www.nickl-partner.com/

Gross floor area: 2,600 $\mathrm{m}^{2}$

Main floor space: $2,200 \mathrm{~m}^{2}$

Collection size: approx. 150,000 print, 400,000 electronic

Staff: 32

Workstations: 250

Building costs: $€ 170,000,000$ (whole Campus)

\section{The History of the Cattle Market}

During the years 1896-1899, a new abattoir in Düsseldorf Derendorf was planned and built by Georg Osthoff and Carl Peiffhoven. The former location of the abattoir, opened in 1876 in Düsseldorf Pempelfort, lacked a connection to the railway 
line and the facility was too small. From 1887 to 1900 the population of Düsseldorf grew from approximately 120,000 inhabitants on 462 ha to 214,000 inhabitants on 996 ha (Huneke 1928; Peiffhoven 1901; Wessing 1904). Around 1900, the boundaries of the city incorporated Gladbacher, Suitbertus and Feuerbach Street, the railway line at Volksgarten, Kettwiger und Ronsdorfer Street, Grafenberg station and the Grafenberg mansion district, the zoological garden, the abattoir, the north cemetery and Homberger Street (Huneke 1928). The increasing population of the city led to a higher demand for meat products and the facility no longer met modern hygiene requirements or technical standards of the time (Peiffhoven 1901).

Georg Osthoff was town councillor for spatial planning and traffic in Berlin and had completed a similar abattoir in Breslau (1894-1896) (Der städtische Viehmarkt und Schlachthof zu Breslau 1897). He published several articles and books on the planning and construction of abattoirs meeting the technical standards of the time (Osthoff 1887; Osthoff 1888). He died in 1898, before the abattoir in Düsseldorf was finished. Carl Peiffhoven also worked in the municipal building department of Düsseldorf as town councillor for spatial planning and traffic and was responsible for expanding the abattoir site.

Between 1925 and 1932, the city infrastructure of Düsseldorf developed rapidly. The airport was opened for civilian travel; the routing of the railway line and the main station were modernised; and state-of-the-art factories were established. New architectural styles emerged. In 1927, the population of the city reached over 400,000 inhabitants (Huneke 1928; Vorsorge für das physische Leben 1928). To meet the growing demand for food following the first World War and the subsequent occupation of the Rhineland, an extension to the cattle market hall was built in 1930 (Heimeshoff 2001). The new part of the hall shows the iconic architectural style known as Neue Sachlichkeit/New Objectivity of the era and features a sober red brick façade (Figure 1), visible concrete cornices, concrete structure and an absence of ornamentation. In this period, the use of red brick was synonymous with hygiene, purity and naturalness and deemed most fitting for a place for food production (Kuhn 2001).

Between 1941 and 1944, the cattle market was shamefully used by the Nazi regime as a collection camp for about 6,000 Jewish men, women and children from Düsseldorf and the surrounding regions prior to deportation. The people were registered, robbed of their property and sent to ghettos in occupied Eastern Europe: Łódź, Minsk, Riga, Izbica and Theresienstadt, now known as Terezín (Lutz 2020). The ghettos were often intermediate stations on the way to concentration camps and extermination sites.

During World War II, numerous buildings on the site of the abattoir were destroyed to a varying extent, some losing up to $90 \%$ of the original built sub- 
stance. The existing, now listed, historic buildings which were the cattle market hall and the equine slaughterhouse, lost some $20 \%$ of their original composition and were rebuilt between 1945 and 1949. During that time, the slaughterhouse operated on a makeshift basis (Gemeindewirtschaftspflege 1949). In the 1950s, the demand for meat products grew as the purchasing power of the city's inhabitants increased, and funding was obtained to reconstruct and modernise the abattoir (Gemeindewirtschaftspflege 1951). In 2002 the abattoir went bankrupt, was closed and virtually abandoned (Figure 2) (Redaktion fleischwirtschaft.de 2002).

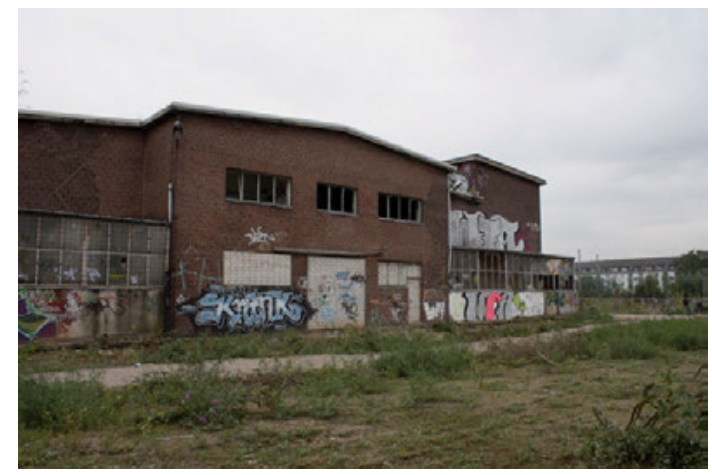

Fig. 2: Exterior before restoration. (C) Robert Niess.

\section{Architectural and Design Principles}

The underlying design principles for today's refurbished building are based on three key elements: the industrial character of the original building; the contrasting interventions built during the 1940s refurbishment; and concepts of openness and connectedness for a modern university facility. An essential design feature in the reuse process was to keep the industrial character of the original building. For the new architectural elements such as the staircase enclosure to the upper floor and the upper floor galleries, exposed concrete was used for the construction. The new elements were designed to be purely functional and the technical infrastructure such as ventilation, sprinklers and electrical systems were installed in an open and visible manner. 


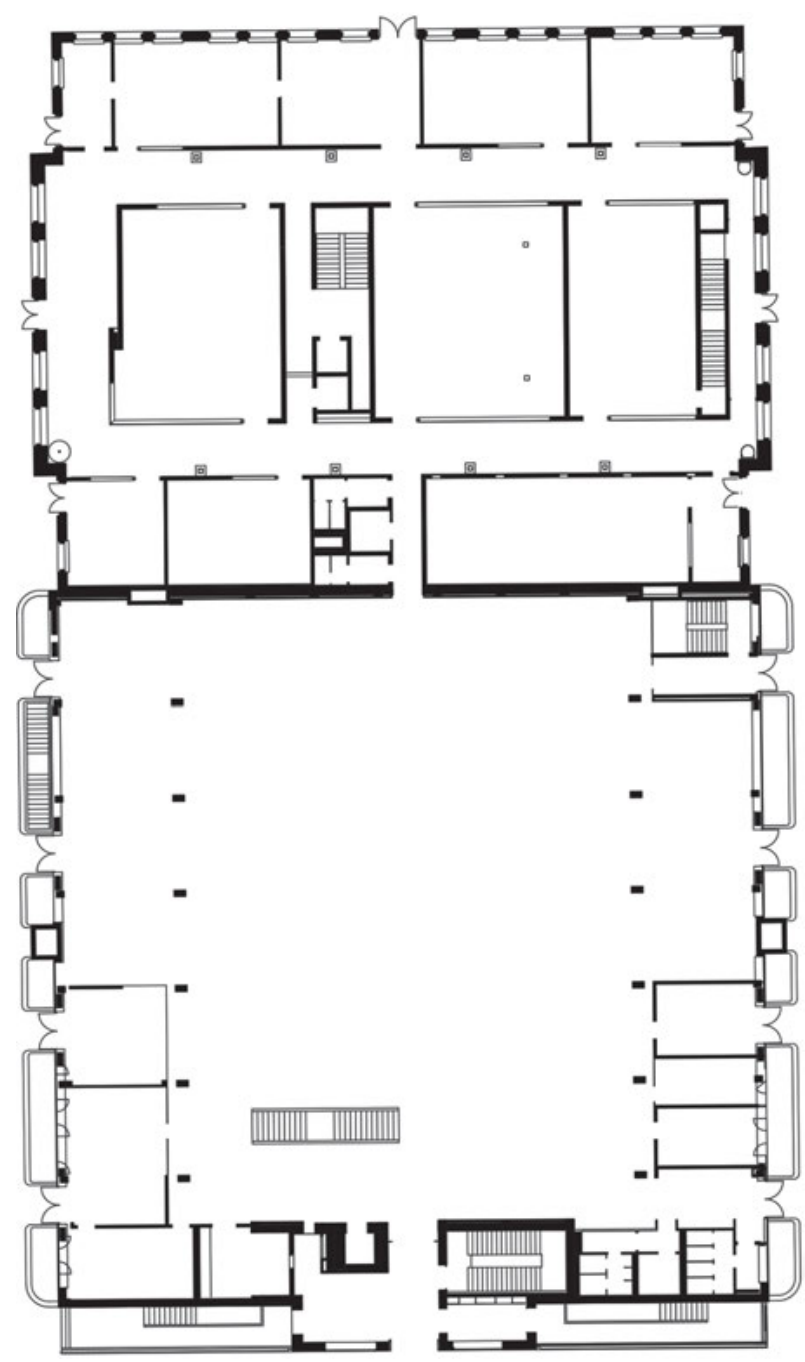

Fig. 3: Ground floor plan. (c) Nickl \& Partner Architekten.

To make the building a pleasant place in which to study, subtle contrasts to the functional design were introduced through the choice of materials and colours. For the fixed furniture, natural and warm materials were used. The worktops have a robust brown-red linoleum surface, and the flooring was made of industrial light oak parquetry (Figure 6). 


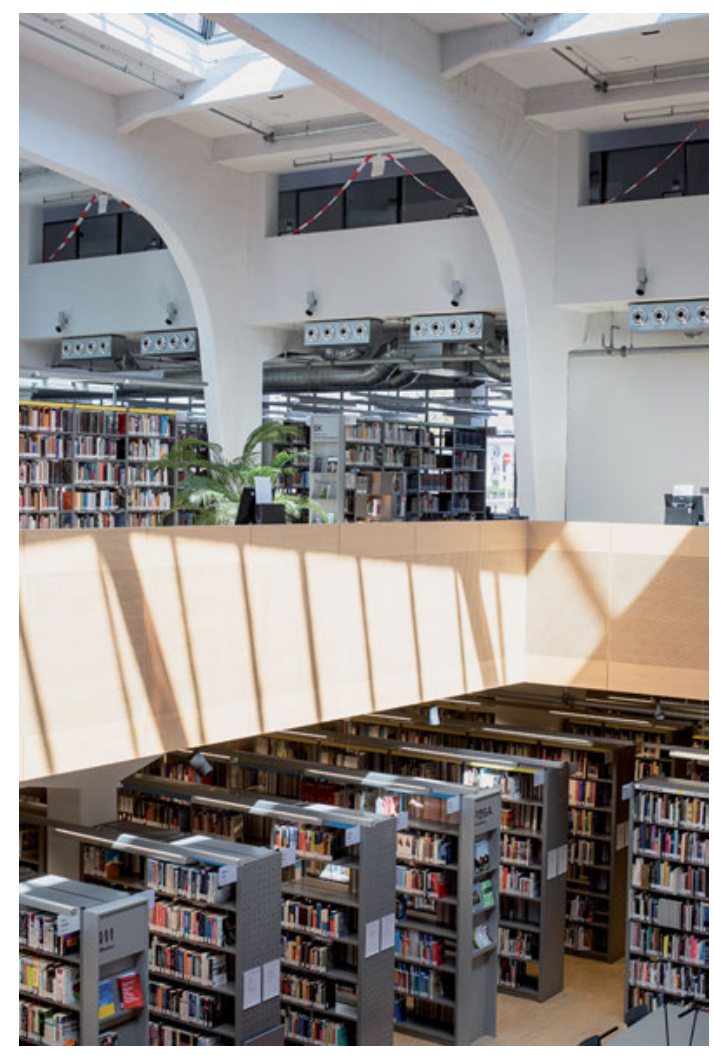

Fig. 4: All floors are visually connected and a visitor can experience the overall expanse of the hall. (c) Chantal Schlenker.

The concept of openness was achieved by making a rectangular opening between the ground floor and the basement level as well as adding galleries to the top floor. All floors are visually connected, and a visitor can experience the overall expanse of the hall (Figure 4). From outside, a sense of openness was created by redesigning the entrance of the building to provide an inviting, showroom-like area with two windows to the foyer inviting the visitor into both the library and the Alter Schlachthof/Old Slaughterhouse Memorial Centre which commemorates the deported Jews of Düsseldorf and its surrounding region. The Centre is in the former side entrance of the building. All changes were made in accordance with the requirements for the protection of the historic building. The redesign of the listed building was undertaken within the context of the newly designed buildings forming the new Campus Derendorf. Integrating the old and the new structures was a driving principle. 


\section{Vision and Demands of the Library}

The vision was to establish an open, communicative space that promotes discussion and interdisciplinary exchange and at the same time provides quiet areas with high amenity for learning, seeking information and concentrated study. The new library building brought together collections and users from three former branch libraries in Düsseldorf Golzheim and Düsseldorf Oberbilk. The new location had to be an attractive place for different types of users with varying needs. A user survey conducted in 2013 showed that depending on the faculty of the respondents and the semester of study, the use of the library ranged from short visits for borrowing books to long stays for discussion and intensive learning.

Free and unlimited access to resources was noted as an important requirement allowing users to browse all physical items without restriction. Other requirements were easily discoverable electronic resources and flexible workplaces that could be adapted for a variety of needs with easy-to-move furniture. A long-term goal was to create a modern and forward-looking academic library that would adapt to the future.

\section{Commemorating the Past}

Moving into a listed building brought the added responsibility of commemorating its past. The Alter Schlachthof Memorial is an integral part of the building. It is located at the entrance, which was the former cattle market reception ramp, and was designed by the architects as an exhibition area. The former cattle ramps have been augmented by two metal staircases forming a circular route through the exhibition. The large glass fronts and roofs covering the ramps provide a view into the exhibition area which includes documents and photographs (Figure 5). The educational and exhibition area was developed by University staff and students in conjunction with the University's Forschungsschwerpunkt Rechtsextremismus und Neonazismus (FORENA)/Centre for Research in Right-wing Extremism and Neonazism and is aimed at university students, teenagers, interested members of the general public and knowledge mediators who seek to learn and share their knowledge with others (Lutz 2020). The permanent exhibition documents the crimes committed and reconstructs the lives and stories of the people of the region who were deported to ghettos and extermination camps. In a digital archive, historical documents, biographical information and photographs portray the victims, perpetrators and profiteers. A stone cattle-feeding trough in the library bears witness 
to reports of parents who placed their children there to protect them from cold and dirt during the night preceding deportation.

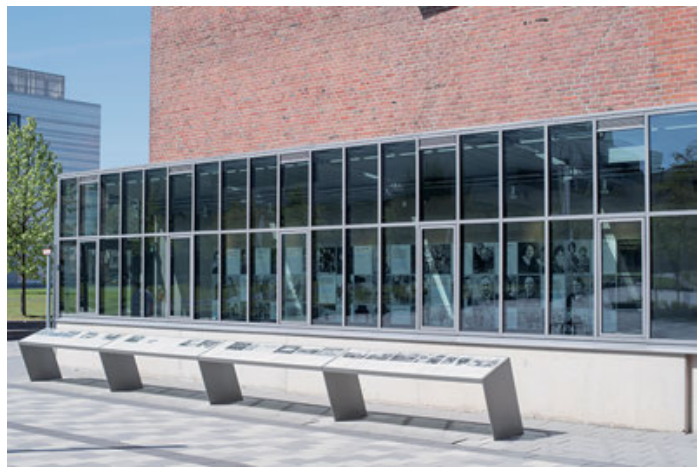

Fig. 5: Alter Schlachthof Memorial: entrance and cattle market reception area redesigned for an exhibition area. (C) Chantal Schlenker.

\section{Space, Noise, Ergonomics and Technical Infrastructure}

Key issues to be addressed in designing the library were layout, noise containment, ergonomics and technical infrastructure. To understand the challenges involved in meeting the issues, it is important to understand the layout of the building. The library has three storeys: a basement floor, a ground floor and an upper floor. All floors are connected visually for good orientation and overview. They are accessible for users via two separate staircases and barrier-free with an elevator. The basement floor has a large ceiling opening to the ground floor with a wooden surround in which shelving for current journals is integrated. The ground and basement floors have parquetry wooden flooring; the upper floor is carpeted. Both flooring types are exceptionally durable. On the upper floor, two former feed storage areas were converted into office spaces and group study rooms. On the ground floor are the service desk, the information office, copying facilities, workstations, current journals, the multiple copy textbook collection and a major part of the main stack (Figure 3). The bound journal volumes, the second part of the main stack, more workstations and study booths are located on the lower level. The lower floor houses a training room used for courses run by the library. 


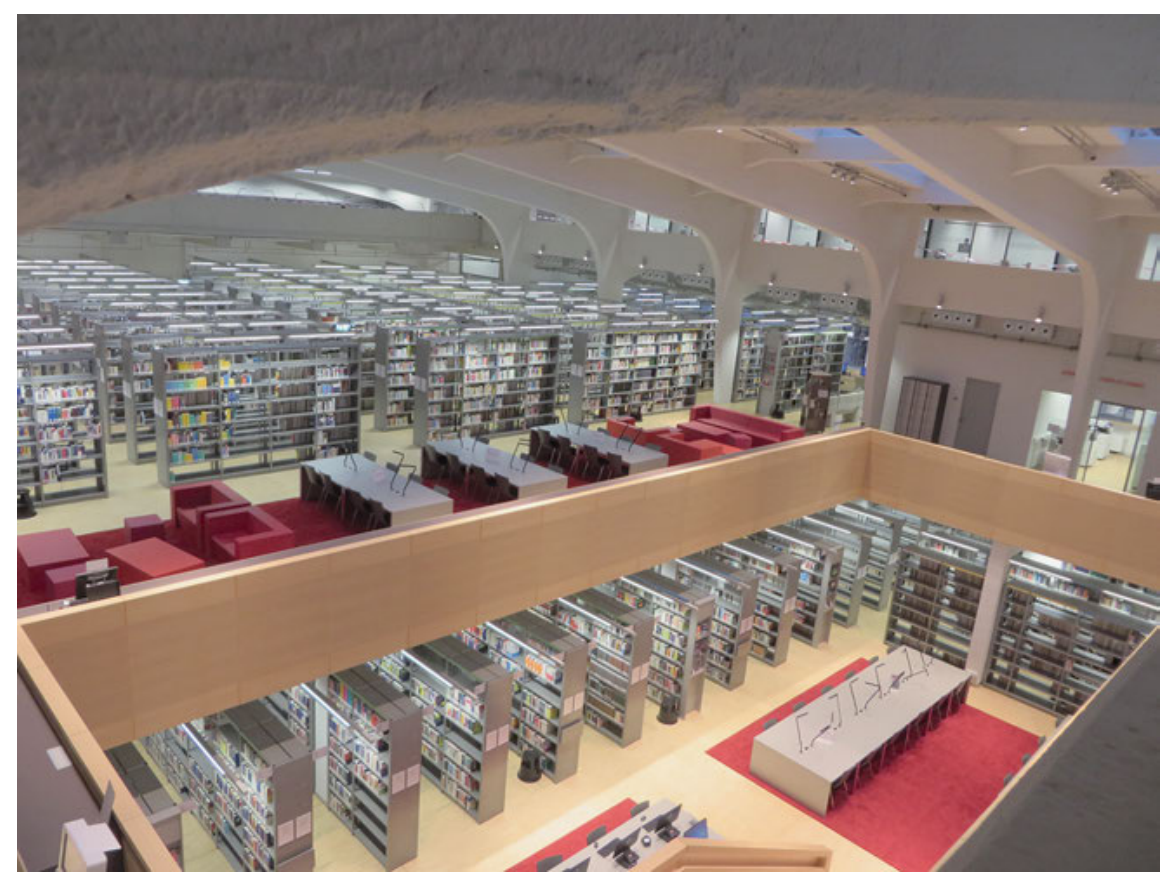

Fig. 6: The open aspect is enhanced by the hall character of the building. ( ) Katharina Regulski.

The open and communicative concept is reflected in the hall-like character of the building (Figures 3 and 6). Having been constructed as a cattle market, the building is wide, airy and well-lit by windows in the shed roof and in the eastern and western walls. However, wide and open spaces present noise containment problems and separating quiet areas from communication zones in the library is challenging. To help delineate the different zones and to add some noise protection, deep-pile red carpets have been installed in the central study zones on the upper and basement floors (Figure 6).

\section{Variety of Workspaces}

The new library aimed at providing a variety of workspaces and areas of the library on the ground and basement floors are equipped with sofas and stools to create an informal and relaxing atmosphere. For quiet research, long workbenches are permanently installed underneath windows on the ground and basement floors, and along the gallery on the upper floor forming carrel-like workplaces. In some 
areas of the library, smaller arrangements of chairs and desks form separate learning environments for quiet study. Four study rooms for individual users are in the basement and there are eight group study rooms on the upper floor. Workplaces without direct daylight access are equipped with task lighting.

Extensive shelving was required for books and journals and competed with the need for more open spaces, casual areas and study places. Space for both the collection and users was needed in the building. Reusing an existing building meant that space available was limited and restricted by the existing structure. Despite the proliferation of e-books and e-journals, housing and expanding the physical collection was still relevant especially for the arts and humanities faculties. Accommodating the collections carried equal weight in the planning process as creating new workspace scenarios for users.

To make room for study areas and to house the entire physical collection, different shelving options were discussed. The poor condition of the old concrete floor prevented the use of compact shelving on the ground floor as the load was simply too great. Locating heavy compact shelves on the basement floor to house bound volumes less frequently used was investigated, but the idea was dismissed as accessibility to the journals was deemed more important. To provide more space for study areas, shelving on the ground floor was increased to a height of seven shelves. Due to the structural limitations, a few of the additional shelving ranges are currently excluded from use.

The group study rooms were furnished at the beginning in different configurations with easy-to-move poufs instead of desks and chairs to provide more creative spaces. Experience has shown that rooms with chairs and desks are preferred by users and subsequently all group study rooms were adapted accordingly.

Mobile furniture is crucial to facilitate reconfiguring of spaces for events such as exhibition openings, readings and lectures. Robust and lightweight, couches and poufs can be moved and stored with little effort, to create large and open areas.

With long-term flexibility in mind, shelves and lighting were designed using a modular system. Sections of shelving can be permanently removed to respond to future requirements such as a need for more specialised workspaces or a decline in the number of items in the physical collection. For the shelves, a standardised product was selected to ensure the continuing supply of add-ons and spare parts. The dark grey metal surface complements the industrial character of the building.

Some of the initial design decisions concerning the interior turned out to be impractical and were later revised. In the first draft plans, all suitable spaces for workspaces or shelves were considered. On the upper floor, chairs and desks were placed in corridors beside the group study rooms. The workplaces conveyed a feeling of seclusion, but the corridors are open to the library and encouraged discussions between groups of students causing constant noise and disturbance 
to others working in the library. Some workplaces were consequently removed or reduced to individual user workplaces. The same problem with noise control occurred in a reception area on the upper floor which had a sofa and casual seats.

The service counter was designed as an item of fixed furniture and follows the shape and style of the building, adopting the characteristic design of linear, rectangular shapes which reflects the atmosphere of the building and supports the industrial theme. From an occupational health and safety point of view, the desk was perceived by the staff to be less ergonomic than the round model used at the former location, despite its being adjustable in height.

The location of offices in the former animal feed stores on the upper floor posed occupational health and safety challenges due to the limitations that come with listed building status. In the original design, the areas did not have proper windows but only small slits in the upper portion of the outer walls three metres in height. Fortunately, the historic protection representatives permitted the windows to be extended to provide more daylight. Glass panes were placed in front of the new windows to preserve the original look. To create a spacious feeling and to avoid confined spaces, two large offices were created in place of the numerous small cells. The spaces are open to the corridor and convey a feeling of openness. The larger spaces enable a workable arrangement of desks, lighting and cross ventilation. Simple lighting using additional daylight lamps produces a diffused natural light. The downside is noise control. In an office area occupied by six to eight people, noise created by phone calls, keyboard clicking, conversations and people walking by makes concentrated work difficult. Mobile acoustic barriers were installed to create more privacy, especially near the corridors.

\section{Retrofitting Implications and Issues}

Many factors were considered when refurbishing the building. The design featured large industrial warehouse windows on the east and west side of the hall and gable skylights on the roof. To respect the original industrial character, new doors and windows were constructed to match the originals. Technical infrastructure like the newly added elevator had to fit existing preconditions within the building. As a result, some items were custom-built and have been more costly to maintain. The newly added glass panes were manufactured with UV protection.

The positive effect is the vast amount of natural light in the building which is great for studying and learning. The effects of glare and high temperatures especially during summer can be a problem. According to the architects, the building is equipped with a ventilation system that draws pre-cooled air from the outside. 
Windows can be opened manually for ventilation. The positioning of the workbenches renders the windows difficult to reach without disturbance to users. To avoid glare and to keep the temperature lower, blinds are installed both at student workplaces and in the offices.

The refurbishment and the requirement for barrier-free access led to an unusual approach for the multi-purpose social space. The designated room was originally accessible via a short stair. As part of the refurbishment, the floor was raised about $70 \mathrm{~cm}$ and levelled which meant that the original windows were at ground level. The solution was to brick-up the windows leaving a silhouette on the exterior façade to indicate their original positions. New windows were added to the east and west side of the room. The new space is now elongated in shape and provides plenty of room for meetings and social events.

The library's location in its own building with separate toilet facilities and an independent technical infrastructure brought new responsibilities for the library staff who work closely with, and report technical and hygiene issues to, the facility management team.

There have been implementation issues with the technical infrastructure. The plans included enough well-distributed power outlets at the workplaces and via floor connectors. However, the distribution of the power connectors was not evenly implemented leaving some workplace areas well-appointed but others poorly equipped. There were insufficient floor connectors which is particularly problematic when holding events as extension cables are unsightly and pose a risk of tripping. Some technical items chosen have proven less than ideal for use in a library. For example, part of the electronic door lock system uses an acoustic signalling when activated which produces additional noise.

\section{Conclusion}

The library has become an extremely popular learning environment and is open seven days a week due to requests from students in 2019. Events such as exhibitions and guided tours take place on a regular basis, with as many as ten events held in 2018. Members of all faculties ask to present student work, lectures and other material in the library which promotes interdisciplinary exchange. By moving into its own building with unique characteristics, the library and its services have become more visible. The profile of the library has improved for both the users and staff. The building demands responsiveness to its past and its current and future use, and a responsibility to its previous occupants and current users, making it a place of commemoration and learning. 


\section{Acknowledgements}

The author thanks Arndt Sänger and Linn Gruß of Nickl \& Partner Architekten for providing information on the design principles applied during the redesign of the building.

\section{References}

“Gemeindewirtschaftspflege. Schlacht- und Viehhof - Amt 63." 1949. In Verwaltungsbericht der Landeshauptstadt Düsseldorf: für die Zeit vom Zeitpunkt der Besetzung der Stadt 1945 bis zum 31. März 1949, edited by Statistisches Amt, 207-10. Düsseldorf.

“Gemeindewirtschaftspflege. Schlacht- und Viehhof - Amt 62." 1951. In Verwaltungsbericht der Landeshauptstadt Düsseldorf: für d. Zeit vom 1. April 1949 bis 31. März 1951, edited by Statistisches Amt, 197-99. Düsseldorf.

Heimeshoff, Jörg, and Norbert Beleke, eds. 2001. Denkmalgeschützte Häuser in Düsseldorf. Mit Garten- und Bodendenkmälern. Essen: Nobel-Verlag.

Huneke, D.W.B. Theodor. 1928. “Der Generalbebauungsplan unserer Stadt.” In Düsseldorf: bauliche Entwicklung. 1918-1928, edited by D.W.B. Theodor Huneke, 57-70. Düsseldorf: Fritz.

Kuhn, Thomas W. 2001. "Ästhetik und Ideologie des Backsteins in der Düsseldorfer Architektur der 20er Jahre." In Die Gesolei und die Düsseldorfer Architektur der 20er Jahre, ed. by Jürgen Wiener, 168-75. Köln: Bachem.

Lutz, Thomas, ed. 2020. “'Alter Schlachthof' Memorial Centre.” Berlin: Stiftung Topographie des Terrors. https://www.gedenkstaetten-uebersicht.de/en/europe/cl/deutschland/inst/ erinnerungsort-alter-schlachth/

Osthoff, Georg. 1887. “Neues in Schlachthöfen großer Städte.” Centralblatt der Bauverwaltung 7 (28): 267-68.

Osthoff, Georg. 1888. “Ueber Düngerstätten auf Schlachthöfen.” Centralblatt der Bauverwaltung 8 (4A): 54-55.

Peiffhoven, C. 1901. “Der neue Schlacht- und Viehhof in Düsseldorf." Zeitschrift für Bauwesen 51 (7): 382-98.

Redaktion fleischwirtschaft.de. 2002. "Aus für Schlachthof in Düsseldorf." afz - allgemeine fleischer zeitung, 13.08.2002 (33). https://www.fleischwirtschaft.de/wirtschaft/ nachrichten/Aus-fuer-Schlachthof-in-Duesseldorf-2409?crefresh=1

“Der städtische Viehmarkt und Schlachthof zu Breslau I-III.” 1897. Deutsche Bauzeitung 31 (67): 417-24; (68): 425-26; (69): 430-34.

"Vorsorge für das physische Leben. Lebensmittelversorgung. Schlacht- und Viehhof." 1928. In Verwaltungsbericht der Landeshauptstadt Düsseldorf: für die Zeit 1. April 1925 - 31, edited by Statistisches Amt, 320-23. Düsseldorf.

Wessing, Ferdinand. 1990. “Der Schlacht- und Viehhof.” In Düsseldorf und seine Bauten, edited by Architekten- und Ingenieurverein Düsseldorf, 269-79. Nachdruck der Ausgabe 1904. Düsseldorf: Schwann. 